\title{
Ecolinguistics in the Grain Lexicon of Mandailing Language
}

\author{
Dharmawati $^{1}$, Dwi Widayati ${ }^{2}$ \\ ${ }_{1}$ Universitas Harapan Medan, Indonesia \\ ${ }^{2}$ University of Sumatera, Indonesia \\ Email: dharmawati66@yahoo.com,dwiwidayati@usu.ac.id
}

\begin{abstract}
The research discusses the study of ecolinguistics in the grain lexicon of the Mandailing language. The purpose of this study was to describe the grain lexicon in the Mandailing community. This research is a qualitative descriptive study using an ecolinguistic approach. This research conducted inManisak Village, Batang Natal District, Madina Regency (Mandailing Natal). The subjects of this study were native speakers of the Mandailing language in Manisak village. The source of this research data is grain speech in the Mandailing community. The data collection technique was carried out by the listening method which began with observation and interviews. The results of this study are first, the acquisition of the grain lexicon found in the Mandailing community in the form of words and phrases. Second, the resulting lexicon refers to three classifications, namely lexicon related to activities or ways of working (verb), lexicon related to material (noun) and lexicon related to nature (ejective).
\end{abstract}

Keywords: lecxicon of grain; ecolinguistics; Mandailing language

\section{Introduction}

Language and environment are two interrelated entities in social life. The study of language and its environment is a field of linguistic and ecological studies, namely an interdisciplinary study called ecolinguistics. Ecolinguistics is a science that studies the environment and language, so that language is closely related to its environment (Mbete 2013: 2). The language environment is a dimension of the environment, namely in terms of physical, physical, and geographical environments in which all languages and their speakers live.

Language can develop due to the number of speakers who use the language. Conversely, if a language is used by speakers with a narrow domain, then the language will certainly be eliminated by the more dominant language that is present in the midst of the community. In connection with this, a lexicon of a language is formed that comes from the physical state of the environment in a society. There are various lexicons in the community, such as agriculture, fishing, forests, mountains, farming and so on. The agricultural lexicon, especially grain, is an element of language that contains a repertoire of words that contain information about the meaning of language units that explain the grain environment.

As technology advances, it affects the development of language, especially on terms that are related to agriculture, especially grain. At this time the number of young people who are no longer interested in agriculture certainly has an influence in mastering agricultural lexicon. This of course will result in the extinction of the variety of lexicon languages, so that efforts are needed in maintaining language as mentioned by Supriyadi (2016: 76) that efforts to maintain the language can be realized in the form of cultural diversity, maintaining ethnic identity, maintaining social adaptability, and increase linguistic sensitivity and psychologically can add a sense of security for children. 
Language plays an important role in human life. Humans use language as a means to communicate. Language is related to the principle of politeness of language which is mentioned the maxims of wisdom, generosity, appreciation, simplicity, consensus and conclusions. So from the six maxims the adolescent must use a lot of maxims which expedite the conversation, cooperate with each other in speaking and give mutual appreciation in speaking and at least the simplicity maxim is needed (Darwis, 2018). Language is a medium of communication between humans. Language is needed by humans because human language can find their needs by communicating. As members of the community who are active in everyday life, people are very dependent on the use of language. In other words, where activities occur, there is also a language activity.

According to Syahrin (2018) the process of producing, processing, organizing, and expressing reality and ideas involving language and mind. The mind functions through language and in language. Only by knowing or knowing something can be captured and understood. Language is human openness to reality. Language and mind are places where reality events occur. Relationship between language and mind can be seen from two sides. First, language is seen as a tool for expressing perceptions, thoughts, and emotions (intumentalism). Second, humans can only perceive, think, and feel because of language (determinism) (Poespoprodjo in Dawud, 2010: 4). A topic that preoccupies experts who study language and thought is the relationship between language and mind, specifically the influence of language on the mind (Nababan, 1992: 156).

Many researches on regional languages in the grain lexicon have been carried out, such as Danang (2020) in his research on agricultural varieties in the Javanese language which produces agricultural lexicon in the form of words and phrases that refer to the lexicon of agricultural work, agricultural materials and equipment, and the lexicon. related to environmental conditions. However, the existence of the use of the Javanese language of agriculture is still maintained. Meanwhile, Dwiani (2018) conducted a study on Agricultural Lexicon in the Maanyan Dayak Community with the results of the study that there were 13 lexicon related to grain production activities, starting from searching for land to harvesting, as well as 25 lexicon related to agricultural equipment in the community maanyan. Research on the eco-agrarian lexicon in the Mandailing community has also been carried out by Kesuma (2015) with research results in the form of an agrarian lexicon in the Mandailing community which contains cultural values such as historical values, welfare values and also socio-cultural values. These lexicons also contain the value of environmental wisdom in the form of the value of mutual cooperation and the value of peace.

One of the areas in North Sumatra that is still working in agriculture is Manisak Village, Batang Natal District, Madina Regency (Mandailing Natal). The area around Manisak Village has the most extensive grain field area compared to other villages which is called Saba Sigantang (Sigantang grain field). The people in this village are people with Mandailing speakers. These people use the Mandailing language when they communicate everyday with other fellow citizens. However, the lack of proficiency of the younger generation in the Mandailing language causes a decrease in the intensity of using the Mandailing language in the village. The lack of attention of the younger generation to grain lexicon is one of the causes of the many missing grain lexicon and even extinction. The situation described above is the background for the author to examine the grain lexicon in the Mandailing language. This study aims to describe the lexicon of the grain field environment in the Mandailing language. 


\section{Review of Literatures}

\subsection{Lexicon}

A lexicon is a collection of lexemes in a language. In everyday use, the lexicon is considered a synonym of a dictionary or vocabulary. Chaer (2007:5) says that the term lexicon comes from an ancient Greek word which means "word", "speech", or "way of speaking". The word lexicon is related to lexeme, lexicography, lexicograph, lexical, and so on.

Sibarani (1997:4) distinguishes the lexicon that refers to the vocabulary, namely "The lexicon includes components that contain all information about words in a language such as semantic, syntactic, morphological and phonologically, while vocabulary is more emphasized on the richness of words owned by someone or something language. The lexicon is also defined as "vocabulary, the language component that contains all the information about the meaning and use of words in language; richness of words that a language has". KBBI (2008: 805).

\subsection{Ecolinguistics}

This study uses ecolinguistic theory to examine the grain lexicon in the Mandailing community. Ecolinguistics is a science used to analyze the fields of language and ecology. The study of ecolinguistics was first introduced by Einar Haugen in his writing entitled Ecology of Language in 1972.

Mbete (2009:11-12) states that ecolinguistics is related to ten areas of study, namely: 1. Comparative historical linguistics, 2. Demographic linguistics, 3. Sociolinguistics, 4. Dialinguistics, 5. Dialectology, 6. Philology, 7. Linguistics. prescriptive, 8. Glotopolitics, 9. Ethnolinguistics, and 10. Typology, dissecting the degree of universality and uniqueness of languages.

\subsection{Grain}

Grain is everything related to grain, whether it concerns the tools used to plant and harvest grain or parts of the grain itself. The plant that produces grain is grain. Grain is the staple food of Indonesian people. From its stature, it can be guessed that grain plants belong to the grass group (Sastrapradja, 2012: 36). These fruits are small in size and are classified as "dried fruit" which cannot open on their own.

\section{Research Methods}

This research is a qualitative descriptive research because this research aims to understand linguistic phenomena in the grain lexicon in the Mandailing language. This research was conducted in Manisak village, Batang Natal district, Madina district (Mandailing Natal). The subjects (informants) of this study were native speakers of the Mandailing language in Manisak village. The source of this research data is grain speech in the Mandailing community.

The data collection technique was carried out by the listening method which began with observation and interviews. This listening technique uses basic tapping techniques and advanced techniques, see conversational engagement, recording, note-taking, and collaboration (Sudaryanto, 2015). The data analysis technique used the equivalent method. This is because the equivalent method is a method whose determining tool comes from outside the language (Sudaryanto, 2015:15). The equivalence method used in the data assessment stage is the referential equivalence method. 


\section{Discussion}

\subsection{Results}

Based on the results of data analysis, the grain lexicon in the Mandailing language in the Mandailing community in Manisak Village who works as a farmer obtained three grain lexicon in the Mandailing community who work as farmers. includes 1) work-related lexicon (verb) which is used to explain how the process of something (work) is done. 2) lexicon related to material (noun) used to name objects used daily in grain, 3) lexicon related to nature (ejective).

The grain lexicon is divided into three groups with the aim of simplifying the data presentation process. From the results of the analysis, it was found that grain lexicon with a total of 98 lexicon, consisting of lexicon related to work (verb) consisting of 18 lexicon, lexicon related to material (noun) consisting of 68 lexicon, and lexicon related to nature (ejective). consists of 12 lexicon. The lexicon grouping data that has been obtained are described in the table below:

Table 1. Mandailing Grain Lexicon Grouping Data

\begin{tabular}{|c|c|c|c|}
\hline No. & Kelompok Leksikon & $\begin{array}{c}\text { Leksikon } \\
\end{array}$ & Total \\
\hline 1. & $\begin{array}{l}\text { Leksikon Yang } \\
\text { Berhubungan Dengan } \\
\text { Cara Kerja }(\text { Verb })\end{array}$ & $\begin{array}{l}\text { Manyuan eme, manyabi, mambon dar, mangga du, } \\
\text { marlupak, mambarati, mambujuri, manahalak, } \\
\text { pamasuk ack, manapui, mangkipas, mamaspa, } \\
\text { mardege, marlungguk, marandilo, manggonion, } \\
\text { mangkarung kon, marincir }\end{array}$ & 18 \\
\hline 2. & $\begin{array}{l}\text { Leksikon Yang } \\
\text { Berhubungan Dengan } \\
\text { Kebendaan (Nomina) }\end{array}$ & $\begin{array}{l}\text { Bondar,bondar karihir, bondar tonga, bondar } \\
\text { buangan, bondar jae, bondar julu, gadu, lupak, } \\
\text { lubang, muara, ombik, pintu ni aek, saba, saba } \\
\text { holbung, saba jae, saba julu, saba pasir, saba udan, } \\
\text { sibarati, sitapangi, sibatangi, sibujuri, tahalak, ulu } \\
\text { ni aek, aek, alak-alak, baju salin, batu, bustak, } \\
\text { burir, buntu-buntu, duhul, irta, karetel, lapung, } \\
\text { lungguk, orsik, porngis, rintop, sagean, singgulu, } \\
\text { sopo, tano, tano na lom-lom, tapu-tapu, tano na } \\
\text { rara, marsialapari, smak, andilo, goni, harung, } \\
\text { induri, indalu, incir/osa ka, jail goni, kadangan, } \\
\text { losung, losung aek, napu, pangkipas, paspasan, } \\
\text { pardegean, panggilingan, timbangan, ubat nihama }\end{array}$ & 68 \\
\hline 3. & $\begin{array}{l}\text { Leksikon Yang } \\
\text { Berhubungan Dengan } \\
\text { Sifat (Ejektiva) }\end{array}$ & $\begin{array}{l}\text { Marmua ra, marsita pa ngi, maraek, marbatu, } \\
\text { marbustak, marchuhut, marirla, markarekel, } \\
\text { marlapung, marorsik, marintop, maramak }\end{array}$ & 12 \\
\hline
\end{tabular}

\subsection{Discussion}

\section{a. Work-Related Lexicon (Verb)}

Lexicons related to working methods (verbs) are lexicons used by farmers in carrying out grain activities for the Mandailing community. There are 13 lexicon of working methods (verbs) used by farmers in farming where these lexicons use the prefixes man- mam- and mar-. The meanings contained in the grain lexicon related to the way of working (verbs) are listed in the table below. 
Table 2.The Meaning of the Lexicon Related to How it Works (Verbs)

\begin{tabular}{|l|l|l|}
\hline No & \multicolumn{1}{|c|}{ Leksikon } & \multicolumn{1}{|c|}{ Makna Leksikon } \\
\hline 1. & Manyuan eme & Menanam Padi \\
2. & Mamyabi & Memanen \\
3. & Mambon dar & Membuat parit \\
4. & Mangga du & Membuat pematang yang besar \\
5. & Marhupak & Mengejakan sawah orang lain \\
6. & Mambarati & Membuat pematang \\
7. & Mambujuri & Membuat pematang yang \\
8. & Manahalak & membujur \\
9. & Pamasuk aek & Membendung \\
10. & Manapui & Menga iri \\
11. & Mangkipas & Memupuk \\
12. & Mamaspa & Mengkipas \\
13. & Mardege & Merontokkan padi dengan kayu \\
14. & Marlungguk & Merontokkan padi dengan kaki \\
& & Menumpukkan tanaman padi yang \\
\hline 15. & Marandilo & Menggunakan tas petani \\
16. & Manggonion & Menggonikan \\
17. & Mangkarung kon & Mengarungkan \\
18. & Marincir & Memakai alat pengangkut hasil \\
& & panendari kayu \\
\hline
\end{tabular}

\section{b. Material-Related Lexicon (Noun)}

Material lexicon (noun) is a material lexicon that is used when the Mandailing people carry out farming activities or materials found in the grain field environment. This material lexicon has a verb lexicon containing the prefix mar in the Mandailing language, namely marsialapari which means red soil. The meanings of the 68 lexicon-related lexicons are explained in table 3 below. 
Table 3. The Meaning of the Lexicon Related to Materials (Noun)

\begin{tabular}{|c|c|c|c|c|c|}
\hline No & Leksikon & Makna Leksikon & No & Leksikon & Makna Leksikon \\
\hline 1. & Bondar & Parit & 34. & Lapung & Gabah hampa \\
\hline 2. & Bondar karihir & Parit pinggir & 35. & Lungguk & tumpukan besar tanaman \\
\hline 3. & Bondar tonga & Parit tengah & & & padi yang telah disabit \\
\hline 4. & Bondar buangan & Parit buangan & 36. & Orsik & Pasir \\
\hline 5. & Bondar jae & Parit hilir & 37. & Porngis & Padi yang berisi \\
\hline \multirow[t]{4}{*}{6.} & Bondar julu & Parit hulu & 38. & Rintop & Miang \\
\hline & Gadu & $\begin{array}{l}\text { Pematang sawah } \\
\text { yang besar/batas }\end{array}$ & 39. & Sagean & $\begin{array}{l}\text { Tumpukan-tumpukan } \\
\text { kecil tanaman padi yang }\end{array}$ \\
\hline & & antara sawah yang & 40. & Singgulu & sudah disabit \\
\hline & & satu dengan yang lain & & & Topi petani dari kain yang \\
\hline 7. & & Petakan sawah & 41. & Sopo & dipakai perempuan \\
\hline 8. & Lupak & Liang dibagian & 42. & Tano & Danau/ saung \\
\hline \multirow[t]{2}{*}{9.} & Lubang & bawah & 43. & Tano na lom- & Tanah \\
\hline & Muara & Muara/ Pertemuan air & & lom & Tanah hitam \\
\hline 10. & & parit & 48. & Tapu-tapu & Topi petani dari kain yang \\
\hline 11. & Ombik & Gambut & & & dipakai laki-laki \\
\hline 12. & Pintu ni aek & Pintu air & 49. & Tano na rara & Tanah merah \\
\hline 13. & Saba & Sawah & 50. & Marsialapari & Bergotong royong \\
\hline 14. & Saba holbung & Sawah yang tidak & 51. & Amak & Tikar Pandan \\
\hline 15. & Saba jae & rata & 52. & Andilo & Tas petani dari kulit kayu \\
\hline 16. & Saba julu & Sawah hilir & 53. & Goni & Goni \\
\hline 17. & Saba pasir & Sawah hulu & 54. & Harung & Karung \\
\hline \multirow[t]{2}{*}{18.} & Saba udan & Sawah pasir & 55. & Induri & Tampi \\
\hline & Sibarati & Sawah hujan & 56. & Indalu & Alu \\
\hline 19. & & Pematang yang & 57. & Incir/osa ka & Alat pengangkut hasil \\
\hline 20. & Sitapangi & melintang & & & panen yang beroda empat \\
\hline 21. & Sibatangi & Saluran air & & & dari kayu dan didorong \\
\hline 22. & Sibujuri & Pematang & 58. & Jait goni & Jarum goni \\
\hline 23. & Tahalak & Pematang yang & 59. & Kadangan & Tas petani dari plastik \\
\hline 24. & Ulu ni aek & membujur bendungan & 60. & Losung & Lesung \\
\hline 25. & Aek & Hulu air & 61. & Losung aek & Kincir angin \\
\hline 26. & Alak-alak & Air & 62. & $\mathrm{Napu}$ & Pupuk \\
\hline 27. & Baju salin & Orang-orang sawah & 63. & Pangkipas & Kipas \\
\hline 28. & Batu & Pakaian kerja petani & 64. & Paspasan & Alat perontok padi dari \\
\hline
\end{tabular}




\section{c. Lexicon Related to Traits (Ejectives)}

There are 12 lexicon related to the nature (ejective) in the Mandailing language. This lexicon is almost the same as the lexicon found in the lexicon related to the way of working (verb) by using the prefixes man- mam- and mar-. However, the meaning of the prefixes manmam- and mar- does not indicate the activities of the Mandailing people's workings in grain paddies, but instead this lexicon explains or gives a description/information to the noun (noun). The meaning of the lexicon related to material is explained in table 4 below.

Table 4. Lexicon Related to Traits (Ejectives)

\begin{tabular}{|l|l|l|}
\hline No & \multicolumn{1}{|c|}{ Leksikon } & \multicolumn{1}{|c|}{ Makna Leksikon } \\
\hline 1. & Marmua ra & Bermuara \\
2. & Marsita pa ngi & Memiliki saluran air \\
3. & Maraek & Berair \\
4. & Marbatu & Berbuah \\
5. & Marbustak & Berlumpur \\
6. & Marduhut & Berumput \\
7. & Marirta & Berkarat air \\
8. & Markarekel & Berkerikil \\
9. & Marlapung & Memiliki gabah hampa \\
10. & Marorsik & Berpasir \\
11. & Marintop & Bermiang \\
12. & Maramak & Bertikar \\
\hline
\end{tabular}

\section{Conclusion}

The grain lexicon in the Mandailing community in Manisak village is divided into 3 parts, totaling 98 lexicon, namely the lexicon related to working methods (verb) consisting of 14 lexicon, the lexicon related to material (noun) consisting of 68 lexicon and also the lexicon related to nature. (ejective) which consists of 12 lexicon. These lexiconuse the prefix manmam- and mar- in verbs that explain verbs or do activities. In adjectives, all words use the prefixes man- mam- and mar-, but these prefixes have no relation to the verb or to do activities. Prefixes on adjectives serve to describe objects (nouns).

\section{References}

Chaer, Abdul. 2007. Lexicology and Indonesian Lexicography. Jakarta: Rineka Cipta.

Danang, TP (2020). Ecolinguistic Studies in the Dynamics of Javanese Speech in Agricultural

Variety in Buddhist Society in Gunung Kelir Hamlet, Kulon Progo. Journal of Buddhism and Science Volume. 6 No.2, 15-25.

Darwis, M. (2018). Politeness Language Analysis in Teenagers Reviewed from Sociolinguistics.

Budapest International Research and Critics in Linguistics and Education (BirLE) Journal Vol I (1): 15-22.

Dwiani, S. (2018). Agricultural Lexicons in the Dayak Maanyan Community (Agriculture Lexicons in the Dayak Maanyan Community). Journal Betang Suar, Vol.13, No.2: 
$217-227$.

Indonesian Ministry of Education (2008). Indonesia Dictionary. Jakarta: Balai Pustaka.

Kesuma Dewi, Dwi Widayati. (2015). The Threats of the Ecoagrarian Lexicon in Angkola/Mandailing Languages: An Ecolinguistic Study. Journal of Linguistic Studies, Vol.12, No. 1, p. 54-76.

Mbete, Aron Meko. (2009). Ecolinguistics: A Prospective Linguistic Perspective. Denpasar: Master and Doctoral Program in Linguistics, Udayana University.

Mbete, Aron Meko. (2013). Brief Writing of Ecolinguistics Rese arch Proposal. Denpasar: Vidia.

Sastrapradja, Setijati D. 2012. The Long Journey of Indonesian Plants. Jakarta: Indonesian Torch Library Foundation.

Sibarani, Robert. (1997). Lexicography. Medan: USU Press.

Sudaryanto. (2015). Language Analysis Methods and Techniques: Introduction to Linguistic Research on Cultural Vehicles. Yogyakarta: Duta Wacana University Press.

Supriyadi. (2016). Maintenance of Minority Languages in Gorontalo Province to Promote Local Culture. Procedure National Seminar on Mother Language IX Denpasar.

Syahrin, A. (2018). Culture Repertoire in Expressive Written Language : Study of Hypothesis of Edward Sapir and Benyamin Lee Whorf. Budapest International Research and Critics in Linguistics and Education (BirLE) Journal Vol I (1): 23-28. 